\title{
THE CORRELATION BETWEEN ENGLISH GRAMMAR COMPETENCE AND SPEAKING FLUENCY
}

\author{
Siska Anisa Kusumawardani ${ }^{1}$, Endah Mardiyani ${ }^{2}$. \\ ${ }^{1}$ IKIP Siliwangi \\ ${ }^{2}$ IKIP Siliwangi \\ 르aynsiska@gmail.com, ${ }^{2}$ mardianiendah4@gmail.com.
}

\begin{abstract}
The objective in this case to examine how English grammar competence can influence speaking fluency. The authorcharity quantitative method, and correlation research design. The population was 170 of tenth grade students from 6 classes, at MAN Cimahi in academic year 2018/2019 and the sample was 34 students from design class. The instruments took grammar test and speaking interview. The student's grammar competence scores (X) and the student's speaking fluency (Y) were analysed and it is found that the distribution of data is not normal. The result of data analysis showed that correlation coefficient (r) equals to 0.259 , larger than social significance value which is 0.05 . the interpretation of the relationship is weak correlation. The Null hypothesis is accepted.
\end{abstract}

Keywords: Grammar Competence, Speaking Fluency

\section{INTRODUCTION}

English is an important language for communication,with language we can share information. In globalization era, we have to major the English language. To master English, we have to strengthen: Listening, Speaking, Reading and Writing. The most needed nowadays is speaking English. Speaking English is used as a second language for communication in some country. Therefore speaking English is important for students to face the era of globalization. The government of Republic of Indonesia has placed English language in the curriculum not only at the secondary school, senior high school, but also at university or institute.

According to (Harmer, 2001) and (Gower, Philips, \& Walter, 1995) in (Wardah, Regina, \& Utami, n.d.2015:3), speaking has many different aspects that including in two major categories: accuracy and fluency.One good sign of speaking, certainly marked also with a good grammatical mastery. It is one part of the category of accuracy. English grammar is main role in English use.Grammar in speaking is very important, so because of that, we have to understand grammar.

Fluency is the ability to speaking spontaneously, without having to stop and pause a lot. It is can be done with habituation so that mutual understanding communication materials can be captured between speakers and listeners.

Some people are more concerned with fluency. Fluency on the other hand, the ability to speak fluently, confidently and at a level consistent with the language community standards. People like the ones who like to keep talking. They have a desire to keep trying a new language without 
mistake. But if it keeps on making a lot of mistakes, it's not impossible to speak, the ideas that these students say are hard to catch. This is in connection with the theory of (Skehan \& Foster, 1999) in (Derakhshan, Khalili, \& Beheshti, 2016:180) which mention that speaking fluency pertains to the ability to produce the spoken language "without undue pausing or hesitation".

\section{Grammar}

In foreign language acquisition accurate understanding is the key of language structure. Every language in the world must have a rule. In English we call it grammar.

(Harmer, 1991) in (Malova, 2016:3) states that Grammar knowledge is essential for competent users of a language. It means that the language user must learn grammar because grammar skills will help students organize words and messages and make it meaningful. Moreover, (A, 1989) in (Arief et al., 2016:3) said that grammar is a model of those linguistic abilities of native speakers of language which enable them to speak fluently. In this case, grammatical competence of the native speaker can be reflected by type of institution which speaker has about their native speaker.

Based on explanations and definitions above, the researcher assumed that grammar is a science of rules that governs the order of sentences, phrases, and words to show some meaning. By knowing the grammar our abilities are improved in using an effective style to train expressions in speaking and writing.

\section{Grammatical Competence}

According to the (Council, 2001) in (Artunduaga, 2013:14) competence is defined as understanding of, and capability to use, the grammatical resources of a language. It is the ability to understand and express meaning through generations and the recognition of well-formed sentences in accordance with these principles (as opposed to memorization and reproduction) them as fixed formulae).

Furthermore, (Chomsky, 1965) in (Maksimova, n.d.:115) defined grammatical competence as theoretical and practical knowledge of a partial number of grammatical rules, which allow generating an infinite number of correct sentences. In addition, (Lock, 1997) in (Agulló \& Rama, 2012:180) mentioned that grammatical competence was acquired with the approach of the rule plus drilling methodology typical of audio lingual or traditional grammar methods.

As defined above, we concluded that the learners have to major grammatical competence progressively.Progressively is to the training of thinking skills to deal with problem solving

\section{Speaking}

Speaking is a tool to share information and idea. It is the first the way to do interaction and communication. According to (Rickheit, Strohner, \& Hans, 2008) in (Efrizal, 2012:127) speaking is a speech or utterance produced by the speaker with the purpose, for the listener to process the intent of the speaker's speech. Moreover,(Bailey \& L, 1994) in (Nunan, 2003:48) stated that speaking is the productive aural/oral skill. It consists of producing systematic verbal utterances to convey meaning. So we can concluded to convey meaning, it can be determined by aural or oral skill.

From the definition above, the researcher can conclude that speaking is the productive aural or oral skill, which is producing utterance or speech from speaker to listener. 


\section{Aspect of Speaking}

According to (Brown, 2003:140) there are several traits in speaking such as pronunciation, fluency, vocabulary, grammar, and comprehensible. Below, the description of some the relevant components of speaking by expert.

\section{Pronunciation}

Pronunciation is considered a sub-discourse skill. (Fraser, 2002) in (Gilakjani \& Branch, 2011:2) explained that his fluent English knowledge includes a number of sub-qualifications in which pronunciation is paramount (other sub-skills of speaking include vocabulary, grammar, and pragmatics).

\section{Fluency}

Fluency is speak slowly at normal speed without hesitation, repetition and the use of harmonious compound statements speech. It deals with the way students to speak fluently. (Matthews, Alan, Spratt, \& Dangerfield, 1991) in (Irawati, 2014:7).

\section{Vocabulary}

According to (Neuman \& Dwyer, 2009) in (Alqahtani, 2015:24) vocabulary can be defined as "words we must know to communicate effectively; words in speaking (expressive vocabulary) and words in listening (receptive vocabulary)".

\section{Grammar}

Grammar is a set of rules that explores the forms and structures of sentences that can be used in a language (Gleason \& Ratner, 2009) in (Uibu \& Liiver, 2015:71).

\section{Comprehension}

(Irianti, 2011:9) stated Comprehension is defined as the ability to understand something by a reasonable comprehension of the subject or as the knowledge of what a situation is really like.

\section{Speaking fluency}

(Fillmore, 1979) in (Yang, 2014:197) stated speaking fluency as : a) the ability to speak for a long time with several interval; b) can create coherent, justified and semantic sentences; c) have appropriate expressions in different contexts d) language use should be creative and imaginative. It means those statement are needed to measure the student's in their speaking fluency. Speaking is part of second language learning and teaching, so it is important for student to speak English fluently.

In addition, (Harmer, 2007) \&(Crowther, Trofimovich, Issacs, \& Saito, 2015) in (Albino, 2017:2) stated the term of speaking fluency is linked to the meaning of "communication". For example, in a conversation, a learner can make a grammatical error, such as Maria live in Cazenga [live vs. lives]), but the learner can still speak the sentence with some fluency. In this case, we can still speak the sentence, although with an error grammatical. But if we often do this one, then the information obtained in a conversation is not perfectly.

Then, (Richards, 2006:14) maintained that the speaking fluency is developed by many variables: the interaction in problem solving tasks, the negotiation of meaning in pair work and the use of communication strategies. It means that, with these variables can help learners in improving speaking fluency.

From the definition above, it can be conclude that speaking fluency is part of the second language and learning, so that by improving speaking fluency it will train grammar ability. 


\section{Criteria of Fluency}

(Ers, Stitutio, \& Lee, 2008) mentioned there are two criteria in determining fluency. First, Hesitation. Hesitation phenomena such as fillers are most likely to occur at the beginning of an utterance or phrase, presumably as a consequence of the greater demand on planning processes at these junctures (Barr, D., 2001) in (Corley \& Stewart, 2008:2) .

Second, Formulaic phrases. (Fonseca, 2018) mentioned that the expression of the formula is associated with the language. SIL (Summer Institute of Linguistic) International defines an idiom as an expression made up of multiple words that function as a meaningful or understandable unit. Idioms are difficult for second language learners because their meaning is not clear when looking at the individual words. Both formulaic phrases and idioms are related to figurative language, or language which does not mean exactly what it says.

\section{The Relationship between Grammar Competence and Speaking Fluency}

As it has been already conveyed by expert about grammar and speaking fluency, both of them are so closely related, they are inseparable. Because, grammar is branch of accuracy. Accuracy and fluency is aspect of speaking. As we can see if people who understand about grammar they will speak more fluently than the others who do not understand about grammar. According to (Richards \& Renandya, W., 2002) in (Abbaspour, 2016:146)grammatical competence helps speakers to use and understand English language structures accurately and immediately, which facilitates their fluency. In addition, they stated that accuracy is the basis of fluency, while fluency is a further improvement of a person's linguistic competence and a better revelation of his/her communicative competence. It means that we should to keep a balance between accuracy and fluency in an English classroom teaching.

\section{METHOD}

This research use a descriptive quantitative research which applies correlation research design, it was choosen because the research will present a correlation between grammar and speaking fluency, and at the end build the conclution based on the data gained. The researcher uses instrument such as : first, interview for speaking. The writer using oral test like interview, which consists of five questions and based on the topic. Second, multiple choice. Test for grammar to gather information from students, grammar test consisting of 20 multiple choices. The last are population and sample, the writers take students eleventh grade at MAN Cimahi, there are 6 classes with all of students are 170. In this research the writers took 34 subjects as sample from population. The writers collected the data from grammar test by numbers of student's correct answer then multiplied 10, then divided 2. From speaking the writers converted the small scores of O'Malley \& Pierce to the scale of 100 as follows; $4=100,3=75,2=50,1=25$. And analysis the data, the writers used Spearman Product Moment formula in SPSS Program. 
Table 1

Speaking Rubric

for Fluency Activity by (J \& Lorraine, n.d.) in (Santos, 2005:3)

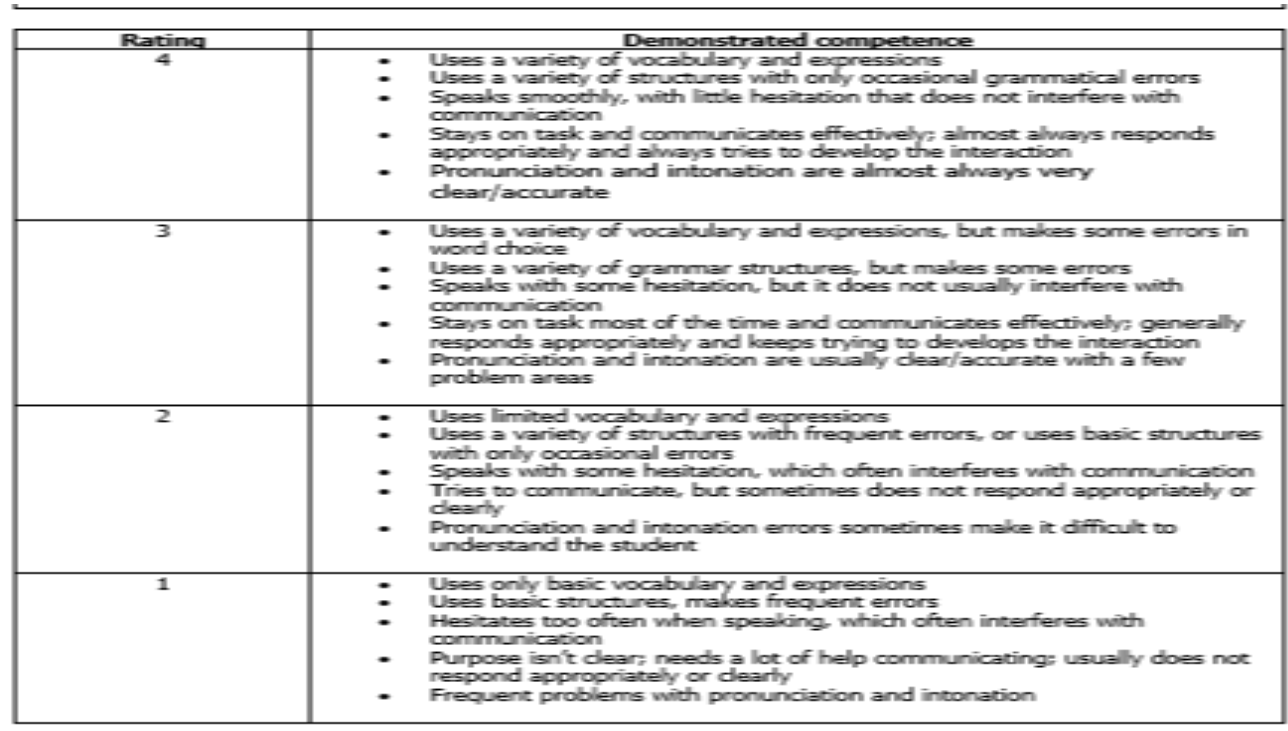

Table 2

Interpretation Correlation by (Siregar, 2013:337)

\begin{tabular}{|l|l|}
\hline Correlation Value (r) & Interpretation \\
\hline $0,00-0,199$ & Very weak \\
\hline $0,20-0,399$ & Weak \\
\hline $0,40-0,599$ & Enough \\
\hline $0,60-0,799$ & Strong \\
\hline $0,80-0,100$ & Very strong \\
\hline
\end{tabular}

\section{RESULTS AND DISCUSSION}

\section{Results}

Test was taken in 13 March 2018 by the eleventh grade students of 34 in MAN Cimahi in academic year 2018/2019. For speaking fluency, the writer gives students time to answer within 3 minutes, it relates to the number of students as 34 people. Every rating has 25 score, the maximum score is 100; means that students can answer the question correctly and the minimum score is 25 , means student can answer the questions with limited. For grammar test, the writer contributed the question to students, and they had 45 minutes to choose the best answer of 20 question. Each number has one point, to get a score; the correct answer will be divided by two, and then multiplied by 10 . 
Table 3

Students Score from Grammar and Speaking test

\begin{tabular}{|c|c|c|c|}
\hline No. & Students & $\begin{array}{c}\text { Grammar } \\
\text { Scores } \\
\end{array}$ & $\begin{array}{l}\text { Speaking } \\
\text { Scores }\end{array}$ \\
\hline 1 & Student 1 & 80 & 75 \\
\hline 2 & Student 2 & 45 & 25 \\
\hline 3 & Student 3 & 60 & 25 \\
\hline 4 & Student 4 & 65 & 50 \\
\hline 5 & Student 5 & 35 & 75 \\
\hline 6 & Student 6 & 75 & 75 \\
\hline 7 & Student 7 & 70 & 25 \\
\hline 8 & Student 8 & 65 & 50 \\
\hline 9 & Student 9 & 65 & 25 \\
\hline 10 & Student 10 & 80 & 75 \\
\hline 11 & Student 11 & 60 & 25 \\
\hline 12 & Student 12 & 60 & 50 \\
\hline 13 & Student 13 & 60 & 25 \\
\hline 14 & Student 14 & 75 & 75 \\
\hline 15 & Student 15 & 55 & 25 \\
\hline 16 & Student 16 & 65 & 25 \\
\hline 17 & Student 17 & 60 & 25 \\
\hline 18 & Student 18 & 80 & 25 \\
\hline 19 & Student 19 & 75 & 25 \\
\hline 20 & Student 20 & 60 & 50 \\
\hline 21 & Student 21 & 50 & 25 \\
\hline 22 & Student 22 & 55 & 50 \\
\hline 23 & Student 23 & 60 & 25 \\
\hline 24 & Student 24 & 65 & 25 \\
\hline 25 & Student 25 & 55 & 25 \\
\hline 26 & Student 26 & 65 & 50 \\
\hline 27 & Student 27 & 40 & 25 \\
\hline 28 & Student 28 & 60 & 50 \\
\hline 29 & Student 29 & 60 & 25 \\
\hline 30 & Student 30 & 60 & 25 \\
\hline 31 & Student 31 & 45 & 25 \\
\hline 32 & Student 32 & 75 & 25 \\
\hline 33 & Student 33 & 55 & 25 \\
\hline 34 & Student 34 & 65 & 25 \\
\hline
\end{tabular}

From the table students' scores above the writers will find the descriptive statistics. 


\section{Table 4}

\section{Descriptive Statistics}

\begin{tabular}{|l|r|r|r|r|r|}
\hline & $\mathrm{N}$ & Minimum & \multicolumn{1}{|c|}{ Maximum } & \multicolumn{1}{c|}{ Mean } & Std. Deviation \\
\hline Grammar & 34 & 35 & 80 & 61.76 & 10.932 \\
Speaking & 34 & 25 & 75 & 37.50 & 18.718 \\
Valid N & 34 & & & & \\
(listwise) & 34 & & & \\
\hline
\end{tabular}

The writer found that the student's grammar competence was good. It is because the mean score of the students was 61.76. The student's speaking fluency was poor. It is because the mean score of students was 37.5

Table 5

One-Sample Kolmogorov-Smirnov Test

\begin{tabular}{|ll|r|r|}
\hline & & grammar & speaking \\
\hline $\mathrm{N}$ & & 34 & 34 \\
Normal Parameters ${ }^{\mathrm{a}, \mathrm{b}}$ & Mean & 61.76 & 37.50 \\
& Std. & 10.932 & 18.718 \\
& Deviation & & \\
Most Extreme & Absolute & .171 & .395 \\
Differences & Positive & .148 & .395 \\
& Negative & -.171 & -.252 \\
Test Statistic & & .171 & .395 \\
Asymp. Sig. (2-tailed) & & $.013^{\mathrm{c}}$ & $.000^{\mathrm{c}}$ \\
\hline
\end{tabular}
a. Test distribution is Normal.
b. Calculated from data.
c. Lilliefors Significance Correction.

It can be concluded that the data from speaking is not normal due to less than 0.05 , and data from grammar is not normal due to less than 0.05 . The conclusions of the data are not normally distributed. The writer find out the correlation between those two variables used the Spearman's product moment to compute the data, because the data was not normal.

Table 6

Analysis result of Spearman rho Correlation

\begin{tabular}{|lll|r|r|}
\hline & & grammar & speaking \\
\hline Spearman's rho & grammar & Correlation Coefficient & 1.000 & .277 \\
& & & .113
\end{tabular}




\begin{tabular}{|c|c|c|c|}
\hline & $\mathrm{N}$ & 34 & 34 \\
\hline speaking & Correlation Coefficient & .277 & 1.000 \\
\hline & Sig. (2-tailed) & .113 & \\
\hline & $\mathrm{N}$ & 34 & 34 \\
\hline
\end{tabular}

From the table above, the correlation between English grammar competence and speaking fluency of the eleventh grade students of MAN Cimahi in the academic year 2018/2019 is 0.277 , which indicated there was weak correlation between two variables. To compute the correlation, the writer prepared the computation of two variables by Spearman's Product Moment. There are two variables; English grammar competence is the first variable and speaking fluency is the second variable.

\section{Discussion}

From this research, the writer found that the student's grammar competence was good. It is because the mean score of the students was 61.76.The student's speaking fluency was poor. It is because the mean score of students was 37.5. The data from speaking is not normal due to less than 0.05 , and data from grammar is not normal due to less than 0.05 . The conclusions of the data are not normally distributed. And for correlation value there is no correlation between grammar and speaking fluency, with significant value is 0.113 , it is larger than 0.05 (social significance value) and it means that "there is no correlation between English grammar competence and speaking fluency". It means that the level of relationship of the correlation coefficient of the two variables is weak.

\section{CONCLUSION}

The aim for this research is to find out there is any correlation between grammar competence and speaking fluency. The result of data analysis shows that as follows; The student's grammar competence was good. It is because the mean score of the students was 61.76. And the student's speaking fluency was poor. It is because the mean score of students was 37.5. For, the significance (2-tailed) is 0.113 , it is larger than 0.05 (social significance value) and it means that "there is no correlation between English grammar competence and speaking fluency". The value of correlation coefficient obtained is 0.277 , while the criteria of the correlation 0.20 to 0.399 are considered weak based on Siregar. It means that the level of relationship of the correlation coefficient of the two variables is weak.

\section{ACKNOWLEDGMENTS}

Praise to Allah who has given us knowledge healthy and opportunity. The accomplishment of this research paper is made possibly because of Allah's help and mercy. Shalawat and salam are presented to our prophet Muhammad SAW, who has brought people from the darkness into brightness age of knowledge. Finally, this final project can be finished on time, the article is entitled "The Correlation between English Grammar Competence and Speaking Fluency".

\section{REFERENCES}

A, R. (1989). Transformational Grammar. New York: Cambridge University Press.

Abbaspour, F. (2016). Speaking Competence and Its Components : A Review of Literature, l(4), 144-152. 
Agulló, G. L., \& Rama, Jo. (2012). The role of grammar teaching : from Communicative approaches to the Common European Framework of Reference for (Vol. 7).

Albino, G. (2017). Improving Speaking Fluency in a Task-Based Language Teaching Approach: The Case of EFL Learners at PUNIV-Cazenga. SAGE, 11. https://doi.org/10.1177/2158244017691077

ALQAHTANI, M. (2015). The importance of vocabulary in language learning and how to be taught. International Journal of Teaching and Education, III(3), 21-34. https://doi.org/10.20472/TE.2015.3.3.002

Arief, M., Universitas, M., Makassar, M., Performance, P., View, T., Muhammadiyah, U., ... Muhsin, M. A. (2016). THE CORRELATION BETWEEN STUDENTS' GRAMMAR KNOWLEDGE AND WRITING ABILITY, (June), 16. Retrieved from https://www.researchgate.net/publication/303761855

Artunduaga, M. T. (2013). Process Writing and the Development of Grammatical Competence. HOW Journal, 20(1), 11-35.

Bailey, K. M., \& L, S. (1994). New Ways in Teaching Speaking. Alexandria. VA: TESOL.

Barr, D., J. (2001). Trouble in mind: Paralinguistic indices of effort and uncertainty in communication. Paris: L'Harmattan.

Brown, H. D. (2003). Language Assessment Principles and Classroom Practices. -. USA: Pearson Education,Inc. https://doi.org/10.1017/CBO9781107415324.004

Chomsky, N. (1965). Aspects of the Theory of Syntax. Cambridge: MIT Press.

Corley, M., \& Stewart, O. W. (2008). Hesitation disfluencies in spontaneous speech: The meaning of um. Linguistics and Language Compass, 2(4), 589-602. https://doi.org/10.1111/j.1749-818X.2008.00068.x

Council, E. of. (2001). Common European framework of reference for languages: Learning, teaching, assessment. New York: Cambridge University Press.

Crowther, D., Trofimovich, P., Issacs, T., \& Saito, K. (2015). Does a speaking task affect second language comprehensibility? Modern Language Journal, 80-95. https://doi.org/:10.1111/ modl.12185

Derakhshan, A., Khalili, A. N., \& Beheshti, F. (2016). Developing EFL Learner's Speaking Ability , Accuracy and Fluency, 6(2), 177-186. https://doi.org/10.5539/ells.v6n2p177

Efrizal, D. (2012). Improving Students ' Speaking through Communicative Language Teaching Method at Mts Ja-alhaq, Sentot Ali Basa Islamic Boarding School of Bengkulu, Indonesia Dedi Efrizal State Institute of Islamic Studies ( IAIN ) Bengkulu, Indonesia Abstract A . Intro, 2(20), 127-134.

Ers, L., Stitutio, I. T. I., \& Lee, C. S. (2008). ACCURACY A D FLUE CY I SPOKE E GLISH AMO G THE ESL by Gred :, (11741), 24.

Fillmore. (1979). Individual differences in language ability and language behavior. New York: Academic Press.

Fonseca, A. (2018, June). What is a Formulaic Phrase? Retrieved from https://classroom.synonym.com/formulaic-phrase-3997.html

Fraser, H. (2002). Change, challenge and opportunity in pronunciation and oral communication. Plenary Address at English Australia Conference. Thomas Nelson and Sons Ltd.

Gilakjani, A. P., \& Branch, L. (2011). A Study on the Situation of Pronunciation Instruction in ESL / EFL Classrooms. Macrothink Institute, 1(1), 1-15. https://doi.org/10.5296/jse.v1i1.924

Gleason, J. ., \& Ratner, N. . (2009). The development of language, 7th edition. Boston: Allyn and Bacon.

Gower, R., Philips, D., \& Walter, S. (1995). Teaching practice. Oxford: Heineman.

Harmer, J. (1991). The practice of English language teaching. Longman. Longman: Longman 
Handbooks for Language Teachings.

Harmer, J. (2001). The practice of english language teaching. Longman.

Harmer, J. (2007). The practice of English language teaching (4th ed.). Edinburgh, Uk: Pearson.

Irawati, I. (2014). IMPROVING STUDENT ' S SPEAKINGABILITY THROUGH COMMUNICATIVE LANGUAGE GAMES, (87), 25-36. Retrieved from http://dx.doi.org/10.5296/jse.v1i1.924

Irianti, S. (2011). USING ROLE PLAY IN IMPROVING STUDEN TS 'Departement of English Education Faculty of Tarbiyah and Teachers ' Training Syarif Hidayatullah State Islamic University Jakarta. Jakarta.

J, M. O., \& Lorraine, V. P. (n.d.). Authen ic As ses s me nt for Engl is h La nguage Learner.

Lock, G. (1997). Functional English Grammar: an Introduction for Second Language Teachers. Cambridge: Cambridge University Press.

Maksimova, M. (n.d.). Cognitive models of grammatical competence 115, 115-122.

Malova, O. (2016). Teaching Children Foreign-Language Grammar : Are Authentic Materials Appropriate? Scandnavian Journal of Intercultural Theory and Practice, 3(2), 33.

Matthews, Alan, Spratt, M., \& Dangerfield, L. (1991). At The Chalkface: Practical Techniques in Language Teaching. Hongkong: Thomas Nelson and Sons Ltd.

Neuman, S. ., \& Dwyer, J. (2009). Missing in action: Vocabulary instruction in pre-k. The Reading Teacher, 384-392.

Nunan, D. (2003). Practical English Language Teaching. (D. Nunan, Ed.) (First). USA: Mc Graw Hill. from http://books.google.com/books?id=v1DMAAAACAAJ\&pgis=1

Richards, J. C. (2006). Communicative Language Teaching Today (First). USA: Cambridge University Press.

Richards, J. C., \& Renandya, W., A. (2002). Methodology in language teaching. New York: Cambridge University Press.

Rickheit, Strohner, G., \& Hans. (2008). Handbook of Communication Competence. Germany.

Santos, N. (2005). World View, 3-5. Retrieved from http://www.pearsonlongman.com/ae/worldview/wvvideospeakingrubric .pdf

Siregar, I. S. (2013). Statistik Parametrik untuk Penelitian Kuantitatif. (F. Hutari, Ed.) (First). Jakarta: Bumi Aksara.

Skehan, P., \& Foster, P. (1999). The influence of task structure and processing conditions on narrative retellings. Language Learning, 1, 93-120.

Uibu, K., \& Liiver, M. (2015). STUDENTS' GRAMMAR MISTAKES AND EFFECTIVE TEACHING STRATEGIES. International Journal of Teaching and Education, III(1), 7087. https://doi.org/10.20472/TE.2015.3.1.006

Wardah, Regina, \& Utami, N. D. (n.d.). An Analysis On Students' Effort To Improve Speaking Skill, $1-10$.

Yang, Y. I. J. (2014). The Implementation of Speaking Fluency in Communicative Language Teaching: An Observation of Adopting the 4/3 / 2 Activity in High Schools in China, 2(1), 193-214. https://doi.org/10.5296/ijele.v2i1.5136 